\title{
Analysis of Mountains Passes along the East-West Continental Divide and Other Drainage Divides Surrounding the Boulder River Drainage Basin, Jefferson County, Montana, USA
}

\author{
Eric Clausen \\ Independent Researcher, Jenkintown, PA, USA \\ Email: eric2clausen@gmail.com
}

How to cite this paper: Clausen, E. (2017) Analysis of Mountains Passes along the East-West Continental Divide and Other Drainage Divides Surrounding the Boulder River Drainage Basin, Jefferson County, Montana, USA. Open Journal of Geology, 7, 1603-1624

https://doi.org/10.4236/ojg.2017.711108

Received: October 26, 2017

Accepted: November 20, 2017

Published: November 23, 2017

Copyright $\odot 2017$ by author and Scientific Research Publishing Inc. This work is licensed under the Creative Commons Attribution International License (CC BY 4.0).

http://creativecommons.org/licenses/by/4.0/

\begin{abstract}
Detailed topographic maps of drainage divides surrounding the Jefferson County, Montana, Boulder River drainage basin were analyzed to determine the nature of drainage systems that preceded today's Boulder River drainage system and how the Boulder River drainage system evolved from those earlier drainage systems. The Boulder River studied here drains in a north, east, and south direction to the Jefferson River, which at Three Forks, Montana joins the north-oriented Madison and Gallatin Rivers to form the north-oriented Missouri River. The North American east-west Continental Divide surrounds the Boulder River drainage basin western half and mountainous drainage divides with the Jefferson and Missouri Rivers surround the drainage basin's eastern half. More than 25 deep mountain passes are notched into these drainage divides and provide evidence of the regional drainage system that preceded the present day Boulder River drainage system. Analysis of pass elevations and of orientations of valleys leading in opposite directions from those mountain passes shows that prior to Boulder River drainage system development immense volumes of south-oriented water moving in anastomosing complexes of diverging and converging channels flowed across the Boulder River drainage basin area and that the Boulder River drainage system evolved as deeper channels progressively captured flow from shallower channels. While not documented in detail crustal warping probably raised Boulder River drainage basin areas relative to adjacent valleys and basins as capture events took place. A water source was not determined, but may have been from a large North American continental ice sheet, although Boulder River
\end{abstract}


drainage basin evolution probably occurred while mid Tertiary sediments were filling adjacent valleys and basins.

\section{Keywords}

Anastomosing Channel Complex, Clark Fork, Jefferson River, Missouri River, Silver Bow Creek

\section{Introduction}

For more than a century since the work of Calhoun [1] and Alden [2] most geologists have believed a continental ice sheet blocked the north-oriented Missouri River in the region north of Great Falls, Montana with the east-oriented downstream Missouri River valley being eroded along that ice sheet's southern margin. The red dashed arrow in Figure 1 at location 1 shows an abandoned northeast-oriented Missouri River valley segment and the red dashed arrow at location 2 shows another abandoned northeast-oriented Missouri River valley segment. While detailed interpretations differ the north-oriented upstream Missouri River valley and the abandoned northeast-oriented Missouri River valley segments are usually considered to have been eroded during mid Tertiary time, perhaps in late Oligocene time, long before any recognized North American continental ice sheets and that ancient north-oriented Missouri River is thought to have flowed across Canada and not to the south-oriented Mississippi River as it does today. As early as 1916 Atwood [3] suggested that sometime after midTertiary time, the north-oriented Missouri River worked its way headward from the Great Falls area and captured southwest Montana drainage in what is today the Jefferson River drainage basin.

Much more recently Sears [4] proposed a major north-oriented river flowing from south of Montana continued along the present day Jefferson and Missouri River valley alignments before continuing in a northeast direction into and across Canada. When in a subsequent discussion Clausen [5] suggested south oriented melt water from a large continental ice sheet was much more likely to have initially eroded what are today north-oriented river valleys Sears [6] replied that mid Tertiary sediments contained in those valleys falsified Clausen's hypothesis. The study reported here continues that discussion by using topographic map interpretation techniques to determine how mountain passes across drainage divides surrounding the present day Boulder River drainage basin originated and evolved. The Boulder River is a north-, east-, and south-oriented river located within the red rectangle shown in Figure 1 (Figure 2 shows the area within the rectangle). The North American east-west Continental Divide curves around the Boulder River drainage basin west half while the Jefferson and Missouri Rivers curve around the Boulder River drainage basin east half. The study reported here used detailed topographic map evidence to determine the nature 


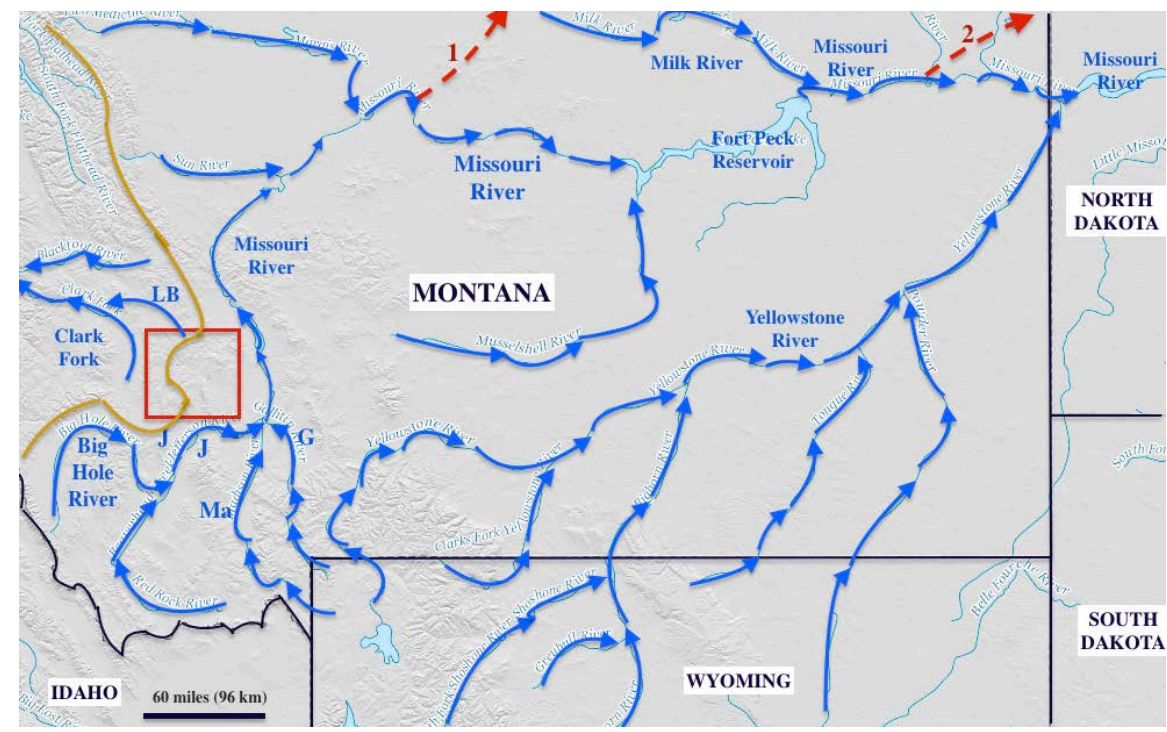

Figure 1. Modified Montana area map from the United States Geological Survey (USGS) National Map website showing the study area (red rectangle) and major drainage routes discussed in this paper. The brown line and Montana-Idaho border show the Continental Divide location. Letters refer to rivers as follows: "G" Gallatin River, "J” Jefferson River, "LB” Little Blackfoot River, and "Ma” Madison River.

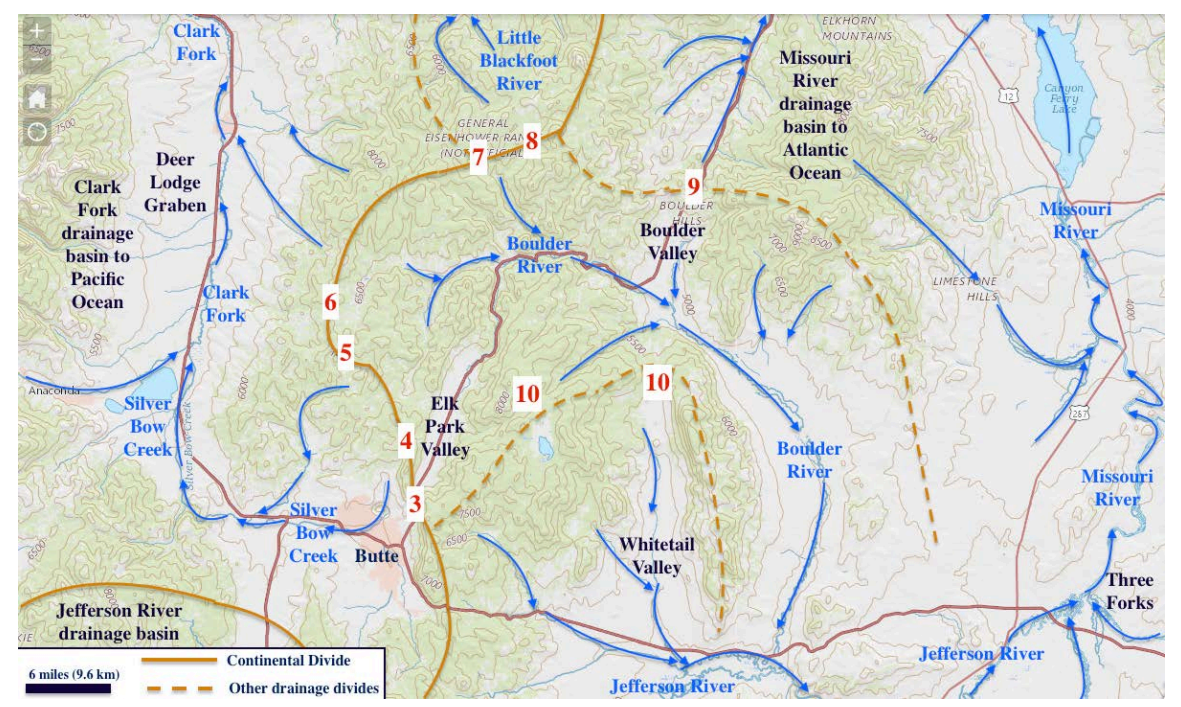

Figure 2. Modified map from the United States Geological Survey National Map website showing drainage basins as identified in the text. The Missouri River flows to the Gulf of Mexico (Atlantic Ocean) while water in Clark Fork eventually reaches the Pacific Ocean.

and direction of flow of the drainage system that preceded the modern day Boulder River.

Figure 2 shows the Boulder River drainage basin area and the Boulder River U-shaped course. Blue arrows and names have been added to emphasize drainage routes discussed in this paper. A brown line shows the east-west Continental Divide approximate position with the Missouri River (Atlantic) drainage basin and Clark Fork (Pacific) drainage basins labeled. Note that the brown line 
does cross the figure southwest corner and the area where the figure scale is shown is in the Missouri River drainage basin with water flowing to the Jefferson River. Red numbers correspond to figure numbers used in this paper and identify approximate locations of detailed maps shown in this paper as figures (the number 10 is shown twice to indicate the larger area that figure covers).

\section{Previous Work}

The Boulder River drainage basin has been extensively studied due to economically important mineral deposits and more recently due to environmental problems those previous mining activities caused, although those studies emphasized priorities other than Boulder River drainage system evolution. Previous studies do describe bedrock underlying the Boulder River drainage basin and also provide insights into the nature of glaciation that occurred along northern Boulder River drainage divides. Church et al. [7] describe the Boulder River watershed as being "largely underlain by the Cretaceous Boulder batholith, which is a large mass of granitic rock that cooled and crystalized at depth, and the overlying Elkhorn Mountains volcanics, which formed as the molten granitic magma erupted... This entire assemblage of granitic and volcanic rocks was later eroded so that lower elevation areas of the watershed, such as valley bottoms, generally are carved through granitic rocks while higher elevation areas, such as ridges and mountain tops, are formed in the overlying volcanic rocks." Woodward [8] describes the Boulder Batholith and adjacent rocks as being the hosts to "numerous metallic mineral deposits found in over 30 mining districts" and "gold, silver, copper, and lead have been produced mainly from fissure veins", but does not address drainage features.

During the mid-twentieth century the United States Geological Survey (USGS) prepared several publications describing Boulder Batholith geology, and while drainage features are briefly mentioned the drainage history is not discussed. In a description of Basin quadrangle geology, which includes large areas of the northern Boulder River drainage basin, Ruppel [9] describes the Boulder Batholith as having been intruded into the folded Elkhorn Mountains volcanics near the close of the Cretaceous. Ruppel also describes quartz latite "of Oligocene age and rhyolite that may be late Miocene-early Pliocene in age" that crops out over much of the central part of the quadrangle. Smedes [10] describes the quartz latite as part of the Lowland Creek volcanics, which are found in the southern part of the quadrangle. Two years later Smedes and Thomas [11] reassigned the Lowland Creek volcanics age to the Eocene and in 2010 different workers confirmed that Eocene age [12]. Ruppel suggests most of the Lowland Creek volcanics were eroded away in some areas before the rhyolite erupted, although Smedes' map shows the quartz latite as an important surface bedrock unit in much of the western half of the Boulder River drainage basin. The rhyolite according to Ruppel "crops out in the northern and central parts of the Basin quadrangle... and at a few localities west of the quadrangle", or in other words at 
localities in the northern Boulder River drainage basin area.

Becraft et al. [13] described the geology and mineral deposits of the Jefferson City quadrangle, which is located immediately to the east of the previously described Basin quadrangle and which includes the Boulder River drainage basin northeast quadrant. Of possible importance when trying to understand Boulder River drainage system evolution they state "During the Pleistocene epoch, most of the stream valleys in the western part of the quadrangle were occupied by glaciers. Glacial erosion modified the topography only slightly, but glacial deposits are widespread. Ground moraine is extensive, and the beds of all major eastward-flowing streams contain thick accumulations of outwash gravel." They also note the presence of "non-mineralized faults of different trends; and probable faults indicated by topographic lineaments" and that "the persistent northeastward trends of many structural features are probably the result of recurring regional forces active since emplacement of the batholith and possibly even before."

Ruppel [14] prepared a separate USGS report describing what he determined to be a Wisconsin age ice sheet that blanketed much of the area between the present day Little Blackfoot and Boulder Rivers. According to his report the ice sheet blanketed an area of approximately 200 square miles (518 square kilometers). Ruppel suggests the glacial deposits, which are primarily till, are the "product of a single glacial episode..." and "the glaciation included three phases: an initial valley-glacier phase, an intermediate mountain-ice-sheet phase, and a final phase in which the mountain ice sheet thinned and the glaciers retreated." He goes on to state that during the ice-sheet phase, the major centers of ice accumulation and the central part of the sheet were in the vicinity of Thiunderbolt and Bison Mountains (on the Little Blackfoot-Boulder River drainage divide) where the ice attained a thickness of more than 1000 feet" (305 meters). The ice sheet's southern limit was mapped as having been north of the Boulder River. Glaciated valleys include those of the north oriented the Little Blackfoot River and of several south-oriented Boulder River tributaries, all of which head along or near the Continental Divide.

The only literature found describing the origins of passes crossing drainage divides surrounding the modern day Boulder River drainage basin was the Alt and Hyndman [15] interpretation that a large south-oriented stream flowing in what is today a wide north-oriented Boulder River tributary valley had flowed through (and probably eroded) Elk Park Pass. In addition they suggest that south-oriented stream had eroded what is today a wide south-oriented Boulder tributary valley and had flowed during a late Miocene a wet, tropical climatic period. Thompson et al. [16] describe regional climates as changing from wet to dry during the late Eocene, dry to wet during the late early Miocene, wet to dry during the early middle Miocene, and from dry to wet during late Miocene-Pliocene times. Retallack [17] noted warm-wet spikes during the "latest Eocene (35 Ma), middle Miocene (16 Ma), late Miocene (7 Ma), and early Pli- 
ocene (4 Ma)."

Somewhat in conflict with the Alt and Hyndman interpretation Sears et al. [18] suggest the same wet, late Miocene climate "filled large lakes and established new through-going drainage systems" including the headwaters of the north-oriented Clark Fork and the north-oriented Missouri River, which today flank the Boulder River drainage basin. There seems to be major problem with one or both of the above interpretations because none of cited authors explains how it was possible for a large south-oriented stream to erode wide valleys and the 1400-foot (427-meter) deep Elk Park Pass and for headward erosion of the present day south-oriented Boulder River valley to behead and reverse flow in that south-oriented stream valley during the same late Miocene time wet period as the north-oriented Clark Fork and Missouri River valleys were being extended southward on either side of the modern day Boulder River drainage basin.

\section{Research Method}

Previously the Boulder River drainage basin region had been studied during the author's much larger and unpublished Missouri River drainage basin landforms origins research project. That multi-year project consisted of systematically studying detailed United States Geologic Survey (USGS) topographic maps covering the entire Missouri River drainage basin and adjacent drainage basins to determine how major drainage divides within and surrounding the large and complex Missouri River drainage basin originated. Drainage divide origins were determined by using divide crossings (through valleys, wind gaps, etc.) as evidence of previous drainage routes and then using barbed tributaries, elbows of capture, asymmetric drainage divides, abandoned headcuts, and similar evidence to determine how many thousands of capture events altered earlier drainage routes so as to produce what are today's Missouri River drainage basin drainage routes. Approximately 550 unpublished and detailed project essays (or research notes) can be found in blog format on the author's

https://geomorphologyresearch.com/ website.

The Boulder River drainage divide mountain pass study described here used detailed topographic maps available at the United States Geological Survey (USGS) National Map website [19]. The U-shaped Boulder River course results in several types of drainage divide crossings. First, passes cross the Continental Divide and link north-oriented Boulder River headwaters and tributaries with south oriented drainage to west and north oriented Silver Bow Creek, which today flows to north- and northwest-oriented Clark Fork with water eventually reaching the Pacific Ocean. Second, passes cross the Continental Divide and link north-oriented Boulder River headwaters with northwest-oriented Clark Fork tributaries. Third, passes cross the Continental Divide and link south-oriented Boulder River tributaries with north-oriented tributaries to the north- and west-oriented Little Blackfoot River, which eventually joins the northwestoriented Clark Fork. Fourth, passes link north-northeast oriented Missouri River 
tributaries with south-oriented Boulder River tributaries. Fifth, passes link south-oriented Jefferson River tributaries with north-oriented Boulder River tributaries. And sixth, passes within the Boulder River drainage basin link various north-oriented Boulder River tributaries.

Each group of passes was analyzed separately before results were combined to determine whether they resulted in a logically consistent pattern that could be used to describe a drainage system that preceded the present-day Boulder River drainage system. Each of the studied passes was first interpreted to have been eroded by a now dismembered drainage route and orientations of valleys now leading away from the pass were then used to determine the orientations of those former drainage routes. The former direction of flow across each of the passes was determined by studying present day streams that now flow in opposite directions from the pass to determine which of the opposing streams is flowing in a valley where the direction of flow has probably been reversed. Types of evidence used in determining former directions of flow included looking for barbed tributaries and stream capture evidence and also looking at gradients of the opposing streams. The spacing of the passes (former drainage routes) was considered when interpreting characteristics of the drainage system that preceded the Boulder River.

\section{Results}

\subsection{Boulder River-Silver Bow Creek Divide Segment of the Continental Divide}

Bison Creek-Silver Bow Creek drainage divide segment: Elk Park Pass (number 1 in Figure 3) with an elevation of 6352 feet (1936 meters) is the deepest pass along the Boulder River-Silver Bow Creek drainage divide segment. East of Elk Park Pass the Continental Divide is oriented in a north-to-south direction and rises in about 2 miles (3.2 kilometers) to elevations greater than 8000 feet (2438 meters) and to the west the Continental Divide rises almost immediately to more than 7500 feet (2286 meters). To the north of Elk Park Pass Bison Creek drains the almost level and broad Elk Park Valley in a north-northeast direction to the east-oriented Boulder River segment approximately 17 miles (27 kilometers) further north. Drainage south of Elk Park Pass is down Woodville Canyon (shown, but not labeled in Figure 3) with water draining to west-oriented Silver Bow Creek in Butte (at an elevation of about 5500 feet or 1676 meters). The asymmetric divide and depth of Elk Park Pass along with southwest-oriented and barbed tributaries joining north-northeast oriented Bison Creek are evidence supporting the previously mentioned interpretation that a large southoriented stream eroded both Elk Park Pass and the Elk Park Valley, although topographic maps cannot be used to confirm the previously mentioned late Miocene erosion date.

Interestingly a pass (at location 1a in Figure 3) links a Bison Creek tributary valley with southeast-oriented headwaters of a Jefferson River tributary. That pass has a floor elevation of approximately 7500 feet (2286 meters) and is 1150 


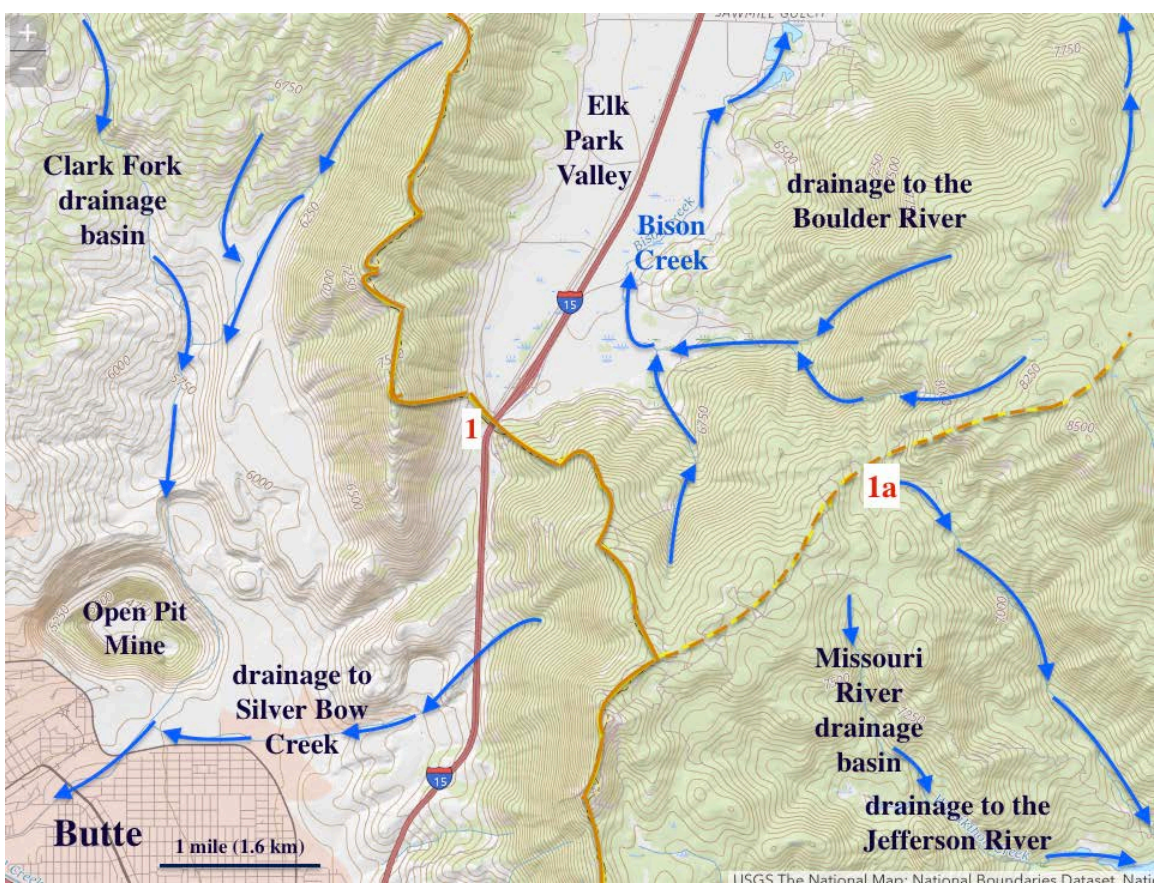

Figure 3. Modified topographic map from the United States Geological Survey National Map website showing the Elk Park Pass area. The brown line shows the Continental Divide and the dashed brown line the Boulder River-Jefferson River divide. The contour interval is 50 feet ( 15 meters).

feet (351 meters) higher than the Elk Park Pass floor elevation, but is more than 500 feet (152 meters) deep. If a south-oriented stream eroded Elk Park Pass then a south-oriented stream must have also eroded the higher elevation pass before deep erosion of the Elk Park Valley (and of Elk Park Pass). If so that higher elevation south-oriented stream on the present day north-oriented Bison Creek alignment and the stream eroding Elk Park Pass must have once diverged with some water flowing along the Elk Park Pass alignment to the present day Butte location and with some water flowing in a southeast direction to erode the higher elevation pass and then to the present day Jefferson River valley. After the higher elevation pass floor had been lowered by more than 500 feet (152 meters) headward erosion of the deeper Elk Park Pass valley must have captured the south-oriented flow moving to the Jefferson River and flow across the higher elevation pass ceased. South-oriented water moving along the alignment of what is now the north-oriented stream in the northeast corner of Figure 3 also eroded what are now southwest- and west-oriented Bison Creek headwaters valleys suggesting an anastomosing complex of bedrock-walled diverging and converging stream channels once crossed the region.

Lowland Creek and Silver Bow Creek drainage divide segment: West of Elk Park Pass the Continental Divide rapidly rises before turning in a north direction and dropping to a gap or pass linking northeast-oriented and southwest-oriented valleys. That gap was probably eroded by southwest-oriented water also diverging from a high elevation south-oriented stream flowing along the 
Bison Creek alignment. Further to the northwest is another pass (unseen and number 3a) across the Continental Divide with an elevation of between 7120 and 7160 feet (2170 and 2182 meters) that links a northeast- and east-oriented Bison Creek tributary with the southwest-oriented Silver Bow Creek headwaters valley and that was also probably eroded by southwest-oriented water diverging from the high elevation south-oriented stream on the Bison Creek alignment. Next the Continental Divide enters the Figure 4 map area and the pass illustrated at location 3 with an elevation of 7258 feet (2212 meters) links the valley of a northand east-oriented Lowland Creek tributary with the valley of a southwest- and south-oriented Silver Bow Creek tributary. Lowland Creek like Bison Creek is a north-oriented Boulder River tributary, but unlike Bison Creek flows in a narrow valley. North and west of Figure 4 a similar pass (unseen and number $3 \mathrm{~b}$ ) crosses the Lowland Creek-Silver Bow Creek divide with a floor elevation of about 6740 feet (2054 meters) and links a northeast-oriented Lowland Creek tributary valley with a southwest-oriented Silver Bow Creek tributary valley.

Perhaps the best clue as to the direction of flow that eroded pass number 3 and pass number $3 \mathrm{~b}$ (north and west of Figure 4) is pass number 2 in Figure 4, which links Lowland Creek with the Elk Park Valley and which has a floor elevation where Lowland Road crosses the drainage divide of 6677 feet (2035 meters), which is only slightly lower than the floor of pass number $3 \mathrm{~b}$ (north and west of Figure 4). There is a gradient differential at pass number 2 with steep slopes leading into the Elk Park Valley and gentle slopes leading to Lowland Creek. This gradient difference strongly suggests water once flowed in a south direction along the present day north-oriented Lowland Creek alignment with one stream of water diverging in an east direction to enter the Elk Park Valley while the other stream of water continued in a southwest direction to erode pass number 3. For reasons not apparent in Figure 4 the Elk Park Valley floor was lowered after most Lowland Creek valley erosion occurred. Eventually headward erosion of the deeper south- and east-oriented Lowland Creek valley from the Elk Park Valley (eroding the pass at location 2) beheaded and reversed south-oriented flow to pass 3 and later to the deeper pass number $3 b$ to create what are today northeast-oriented Lowland Creek tributaries.

Boulder River headwaters-Silver Bow Creek divide segment: Four divide crossings or passes with approximately the same floor elevations can be seen in Figure 5 and they link north-oriented Boulder River headwaters valleys with south-oriented valleys draining to south-oriented Brown's Gulch, which flows to Silver Bow Creek. Pass number 4 has a floor elevation of between 7280 and 7320 feet (2219 and 2231 meters), pass number 5 has an elevation of 7303 feet (2226 meters), pass number 6 an elevation of between 7180 and 7220 feet, and pass number 7 an elevation of between 7200 and 7240 feet (2195 and 2207 meters). East of pass number 4 the Continental Divide rises to an elevation of more than 7800 feet (2377 meters) before decreasing. Between pass number 4 and pass number 5 the Continental Divide rises to 7533 feet (2296 meters), between pass number 5 and pass number 6 to more than 7460 feet (2274 meters), between 


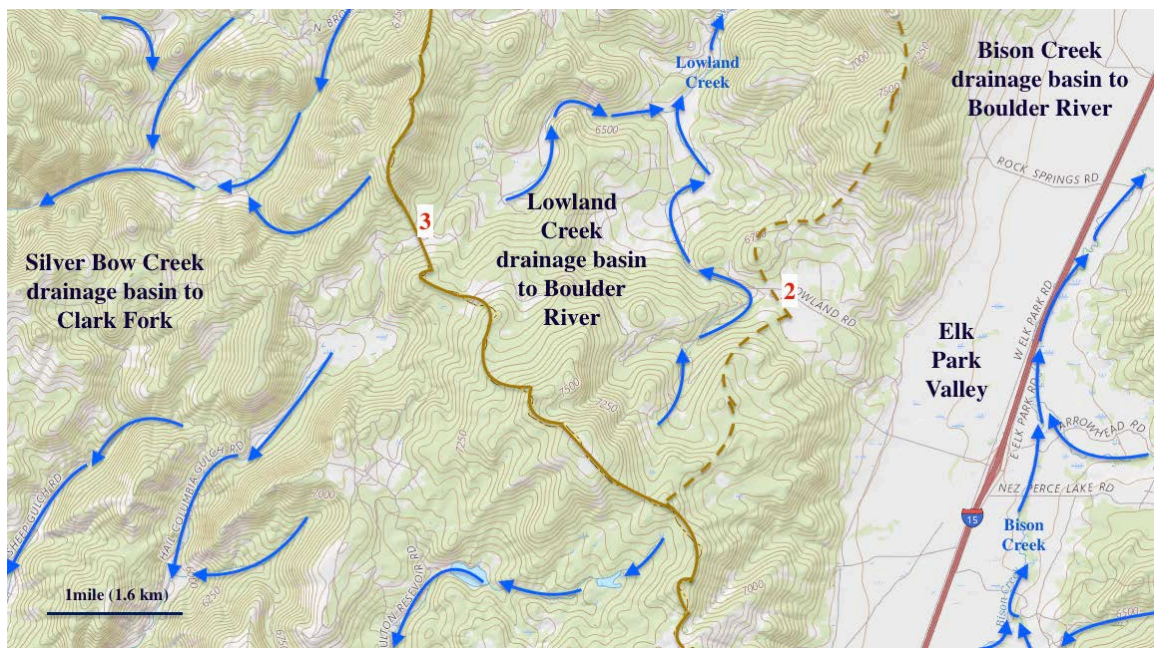

Figure 4. Modified topographic map from USGS National Map website showing the Lowland Creek-Silver Bow Creek drainage divide. The solid brown line follows the Continental Divide and the dashed brown line follows the Lowland Creek-Bison Creek divide. The contour interval is 50 feet ( 15 meters).

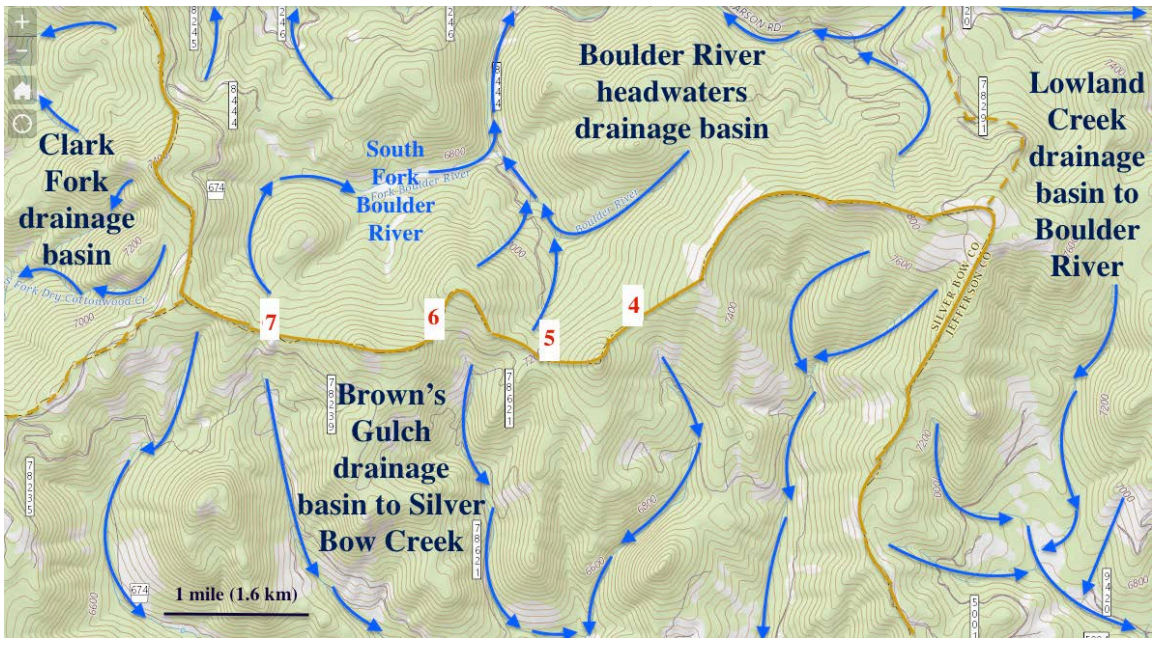

Figure 5. Modified topographic map from USGS National Map website showing the Boulder River headwaters-Brown's Gulch drainage divide. The brown line follows the Continental Divide and the dashed brown lines follow other major drainage divides. Red numbers identify passes discussed in the text. The contour interval is 40 feet ( 12 meters).

pass number 6 and pass number 7 to 7567 feet (2308 meters), and west of pass number 7 to more than 7360 feet (2243 meters) before becoming the drainage divide between the Boulder River and Clark Fork (discussed in the next section below). The similarity of the four pass floor elevations suggests all four passes were eroded by the same drainage system, which based on flow directions determined for other passes along the Boulder River-Silver Bow Creek drainage divide almost certainly must have been in a south direction.

The four closely spaced passes seen in Figure 5 suggest south-oriented streams of water diverged from the present day north oriented Boulder River headwaters valley into four separate channels before converging again in what is 
today the south-oriented Brown's Gulch valley (see Figure 2). The possibility of additional higher elevation diverging and converging channels is suggested by the presence of opposing Boulder River and Brown's Gulch tributaries seen east of pass number 4 and also by the south-oriented headwaters of an east-oriented tributary to north-oriented Lowland Creek seen near the east edge of Figure 5. These diverging and converging channels must have eroded what Baker [20] describes as bedrock-walled anastomosing channel complex. The multiple passes now crossing the Boulder River-Silver Bow Creek drainage divide segment of the Continental Divide and described in this section appear to have all been components of a much larger south-oriented anastomosing channel complex that was captured south of Figure 5 by headward erosion of the much deeper west-oriented Silver Bow Creek valley.

\subsection{Clark Fork-Boulder River Headwaters Divide Segment of the Continental Divide}

Figure 6 shows the drainage divide between north-oriented Boulder River headwaters and the north-oriented Clark Fork. Some of the previously discussed Boulder River-Silver Bow Creek drainage divide area is also seen in Figure 6, although in less detail than in Figure 5. Not seen in Figure 6, but seen in Figure 2 is Silver Bow Creek, which flows in a west direction from Butte before entering the Deer Lodge Graben south end where today it turns to flow in a north direction to join Warm Springs Creek (near location A in Figure 6) to form the north-oriented Clark Fork. Clausen [21] implied that prior to turning in a north direction the west-oriented Silver Bow Creek headwaters turned to flow in a

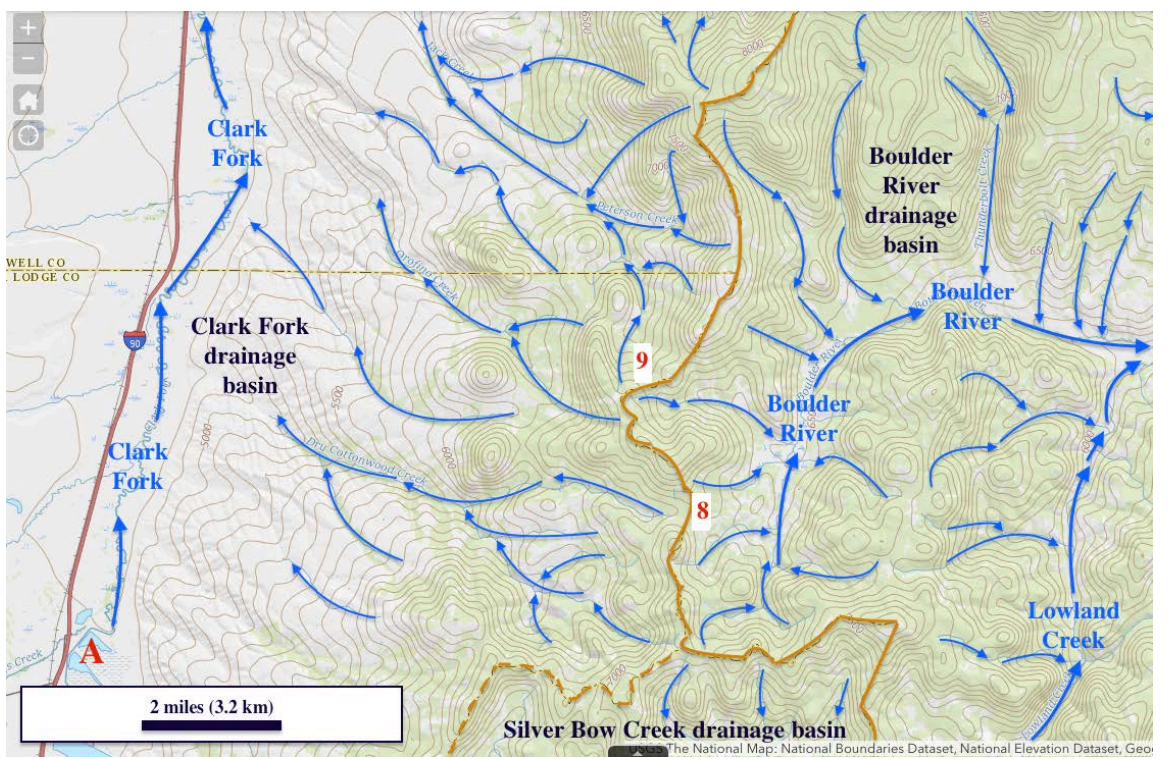

Figure 6. Modified topographic map from USGS National Map website showing Clark Fork-Boulder River divide segment of the Continental Divide. The brown line follows the Continental Divide and the dashed brown line follows the divide between south-oriented drainage to Silver Bow Creek, and northwest-oriented drainage to Clark Fork. Red numbers identify passes discussed in the text. The contour interval is 100 feet (30.5 meters). 
south direction across the Continental Divide at what is today Deer Lodge Pass to join the south-oriented Big Hole River, which today flows to the northeast-oriented Jefferson River. Sears and Ryan [22] interpret the north-oriented Clark Fork to have formed by mid Miocene time and also describe the Clark Fork valley floor as being eroded into thick Tertiary lacustrine and alluvial deposits that fill the Deer Lodge Graben through which the Clark Fork is flowing "about $70 \mathrm{~m}$ [230 feet] below the middle Miocene paleovalley strath-terrace, which is preserved as a prominent bench along the course of the river, locally with remnants of Miocene stream gravel. The modern valley floor is typically underlain by $\sim 15 \mathrm{~m}$ [49 feet] of Quaternary gravel."

Two deep passes and several shallower passes are notched into this Clark Fork-Boulder River drainage divide segment of North America's Continental Divide. The deeper of the two deep passes is number 8 and links an east- and northeast-oriented Boulder River tributary valley with the valley of a northwest-, west-, and northwest-oriented Clark Fork tributary. The floor of pass number 8 has an elevation of between 6800 and 6840 feet (2073 and 2085 meters) and is more than 400 feet (122 meters) below the Continental Divide elevation to the north and south. The second of the deeper passes (number 9) is named on detailed topographic maps as Champion Pass and has a floor elevation of between 6920 and 6960 feet (2109 and 2121 meters), which is more than 500 feet (152 meters) below nearby Continental Divide elevations. Both passes and other passes notched into this Continental Divide segment appear to be erosional features carved by streams or rivers flowing in one direction or the other, however the direction of flow is not immediately obvious and could have changed after south-oriented flow across the Boulder River headwaters-Silver Bow Creek drainage divide segment ended.

Passes number 8 and 9 and several other passes notched into this Boulder River headwaters-Clark Fork Continental Divide segment are lower in elevation than passes notched into the previously discussed Boulder River headwaters-Silver Bow Creek divide segment suggesting after water ceased to flow in a south direction across the Boulder River headwaters-Silver Bow Creek drainage divide water continued to flow across this Boulder River headwaters-Clark Fork drainage divide segment. At least two different interpretations can explain the topographic map evidence with both interpretations beginning with southoriented streams of water moving along the present day north-oriented Clark Fork alignment at a time when elevation differences seen in Figure 6 did not exist. Both interpretations begin with southeast-oriented water moving from the present day north-oriented Clark Fork valley to the diverging and converging valley complex that eroded passes number $4,5,6$, and 7 across what is today the Boulder River headwaters-Silver Bow Creek drainage divide segment.

The two interpretations differ when water ceased to flow across the Boulder River headwaters-Silver Bow Creek drainage divide with the first interpretation interpreting that change to mean head ward erosion of the east-oriented Boulder River valley had beheaded and reversed south-oriented flow on the modern day 
north-oriented Boulder River headwaters alignment. This first interpretation then assumes southeast-oriented streams of water continued to flow from the Clark Fork valley area into the Boulder River headwaters region and eroded the north-oriented Boulder River headwaters valleys and helped to erode the deep downstream Boulder River valley and perhaps even the deep Elk Park Pass valley. Eventually elevation difference caused by Deer Lodge Graben subsidence and perhaps by uplift of the Boulder River drainage basin area caused reversals of flow that created the present day northwest-oriented Clark Fork tributaries.

The alternate interpretation assumes subsidence in the Deer Lodge Graben caused reversals of flow along the southeast-oriented diverging channels leading from the Deer Lodge Graben area to the Boulder River headwaters area. These reversals of flow captured south-oriented water that had been flowing across the Boulder River headwaters-Silver Bow Creek drainage divide and diverted that flow in a west and northwest direction into the subsiding Deer Lodge Graben where drainage was being reversed to the create the north-oriented Clark Fork seen today. This second interpretation requires south-oriented water from north of the Boulder River drainage basin to have eroded the Boulder River headwaters valleys, with the south-oriented flow in the present day north-oriented Boulder River headwaters valleys being beheaded and reversed by headward erosion of the east-oriented Boulder River valley. With both interpretations tectonic activity played an important role in creating elevation differences that now exist.

\subsection{Little Blackfoot River-Boulder River Divide Segment of the Continental Divide}

The Little Blackfoot River is a north- and west-oriented tributary joining Clark Fork as seen in Figure 1. Figure 7 shows the Continental Divide segment located south of the north-oriented Little Blackfoot River headwaters. West of the north-oriented Little Blackfoot River headwaters are west- and northwest oriented Clark Fork tributaries while south and east of the Continental Divide are south- and southeast-oriented Boulder River tributaries. As previously mentioned a Wisconsin age mountain ice sheet covered the entire Figure 7 and Figure 8 map areas and was thickest between Thunderbolt Mountain (seen in Figure 7) and Bison Mountain (seen in Figure 8), although the ice sheet is not reported to have deeply eroded the region and the map evidence shows no evidence of deep glacial erosion. Passes notched into this Continental Divide segment are not the result of ice erosion, but originated when streams or rivers flowed across the region.

Passes numbered 10 and 11 link northwest-oriented Clark Fork tributaries with south-oriented Boulder River tributary valleys and have floor elevations exceeding 7900 feet (2408 meters). Passes numbered 12 and 13 are much deeper and are located between Electric Peak and Thunderbolt Mountain and link the north-oriented Little Blackfoot River headwaters valley with a south-oriented Boulder River tributary (Thunderbolt Creek). Pass number 12 has a floor elevation of between 7440 and 7480 feet (2668 and 2280 meters) and pass number 13 


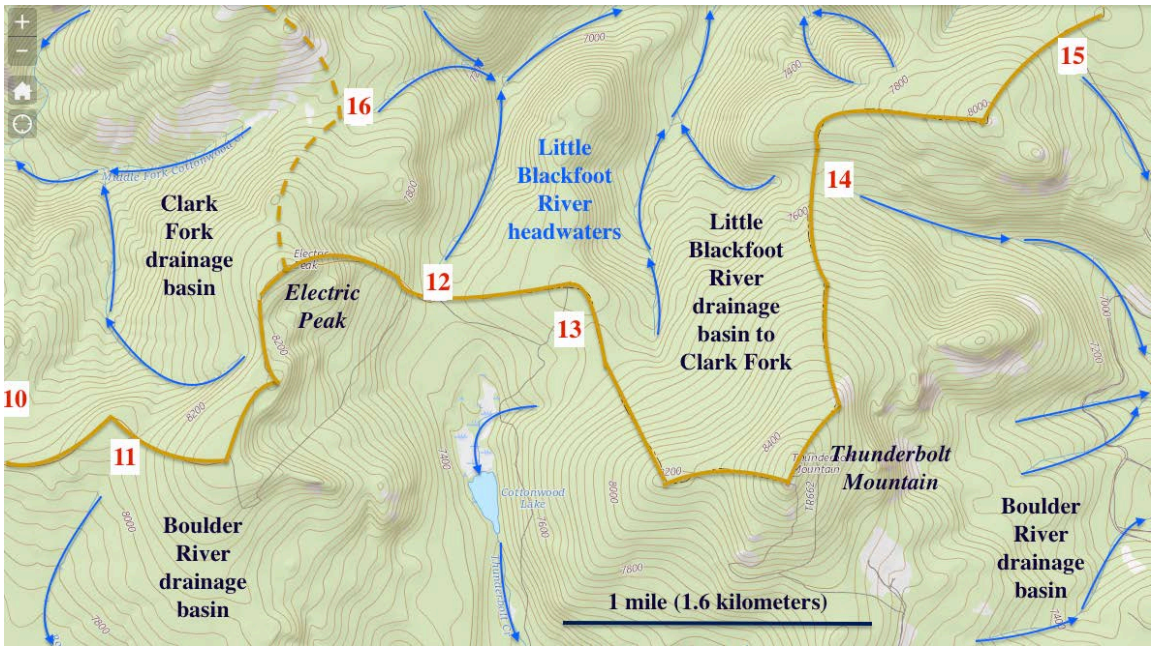

Figure 7. Modified topographic map from the USGS National Map website showing a section of the Continental Divide segment between the Little Blackfoot River and Boulder River drainage basins. The contour interval is 40 feet (12 meters).

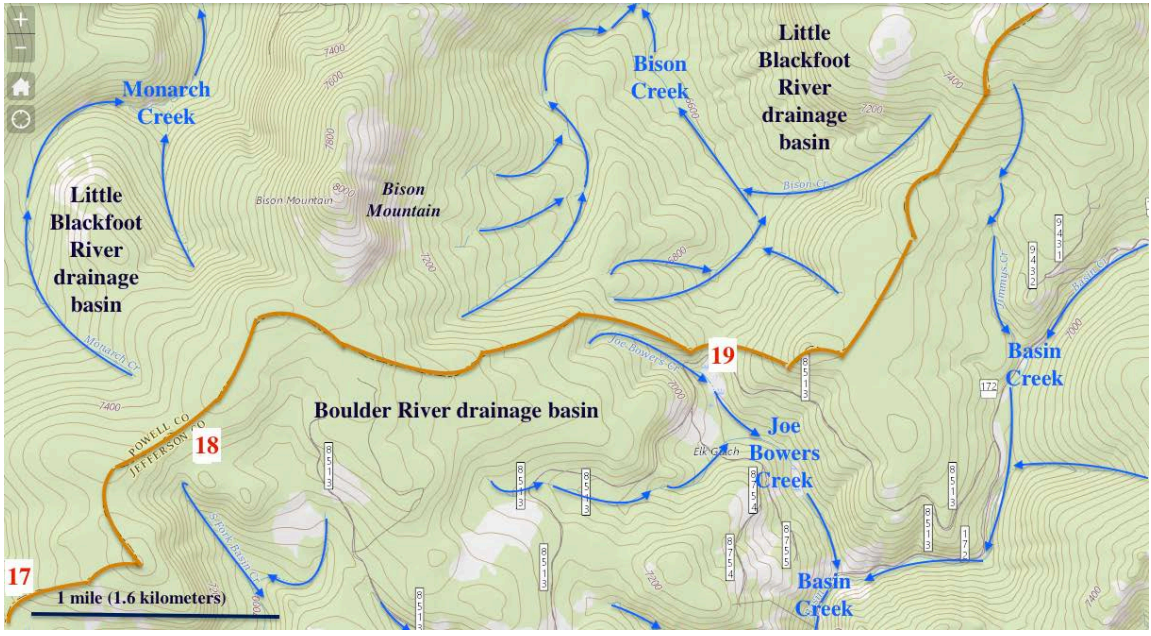

Figure 8. Modified topographic map from USGS National Map website showing the Continental Divide segment near Bison Mountain. The brown line follows the Continental Divide and numbers identify passes discussed in the text. The contour interval is 40 feet (12 meters).

has a floor elevation of between 7560 and 7600 feet (2304 and 2316 meters) while Electric Peak rises to more than 8320 feet (2536 meters) and Thunderbolt Mountain to 8597 feet (2620 meters). Based on these elevations pass number 12 is more 800 feet (244 meters) deep and the larger gap between Electric Peak and Thunderbolt Mountain was probably eroded by diverging and converging south-oriented streams of water with the final flow moving through pass number 12. Water movement across pass number 12 probably ended when tectonic activity enabled head ward erosion of a deeper northwest-oriented Little Blackfoot River tributary valley (north of Figure 7 and Figure 8) to behead and reverse the south-oriented flow so to create the north-oriented Little Blackfoot River headwaters drainage route and to create the modern day Little Black- 
foot-Boulder River drainage divide.

As seen on Figure 7 passes crossing this high Continental Divide segment are common. Pass number 14 with an elevation of between 7480 and 7520 feet (2280 and 2292 meters) links the north-oriented Little Blackfoot River headwaters valley with still a different southeast-oriented Boulder River tributary valley (Red Rock Creek). Elevations of passes number 12 and 14 are similar suggesting they were eroded by streams diverging from the same south-oriented stream. Pass number 15 also links the north-oriented Little Blackfoot River valley with southeast-oriented Red Rock Creek valley and just beyond the northeast corner of Figure 7 is a much deeper pass (number 17 on Figure 8), with a floor elevation of between 7280 and 7320 feet (2219 and 2331 meters) that links the north-oriented Little Blackfoot River with yet another different southeast-oriented Boulder River tributary (Basin Creek). Pass number 16 links the south-oriented valley across pass number 12 with a west- and northwest-oriented Clark Fork tributary valley and can be interpreted in two different ways just like passes numbered 8 and 9.

The deepest pass across the Little Blackfoot River-Boulder River drainage divide (number 19) is seen in Figure 8, which shows the region immediately to the northeast of Figure 7. Pass number 19 has a floor elevation of between 6840 and 6880 feet (2085 and 2097 meters) and links north-oriented Bison Creek with south-oriented Joe Bowers Creek, which flows to south-oriented Basin Creek and then to the Boulder River. Bison Creek flows in a north direction to join northwest-oriented Ontario Creek, which north of Figure 7 joins the north- and west-oriented Little Blackfoot River. Head ward erosion of this deeper southoriented valley from the Boulder River valley beheaded and reversed flow in all other north-oriented Little Blackfoot River tributary and headwaters valleys and ended flow across all other passes seen in figures 7 and 8 . Pass number 18 seen in Figure 8 has a floor elevation of between 7440 and 7480 feet (2268 and 2280 meters) and links north-oriented Monarch Creek with south-oriented Basin Creek. North of Figure 8 Monarch Creek joins northwest-oriented Ontario Creek. The previously mentioned pass number 17 is located at the southwest corner of Figure 8 and northeast corner of Figure 7.

The closely spaced passes seen in Figure 7 and Figure 8 suggest multiple south-oriented streams of water diverged from what is today the north-oriented Little Blackfoot River headwaters alignment and flowed across what is now the Continental Divide before converging again in the Boulder River valley. Diverging and converging streams eroded a bedrock-walled anastomosing channel complex where channels able to erode deeper valleys beheaded and reversed flow in shallower channels so as to begin to create the drainage divide seen today. Head ward erosion of the deep valley across pass number 19 in Figure 8 ended south-oriented flow across all other passes seen in figures 7 and 8 . Flow across pass 19 ended when head ward erosion of the deep west-oriented Little Blackfoot River valley (north of Figure 7 and Figure 8) beheaded and reversed southoriented flow in the present day north-oriented Little Blackfoot River headwa- 
ters valley.

\subsection{Missouri River-Boulder River Drainage Divide}

A short distance north and east of Figure 8 the Continental Divide and the Boulder River drainage divides separate with the Continental Divide turning in a north direction and the Boulder River drainage divide turning in an east and then southeast direction so as to becomes the divide between the Missouri River drainage basin to the north and northeast and the Boulder River drainage basin to the south and southwest. Several noticeable passes crossing the west-to-east oriented Missouri River-Boulder River divide segment link headwaters of north-oriented tributaries to north-oriented Prickly Pear Creek (which flows to a northwest-oriented Missouri River segment near Helena) with south-oriented Boulder River tributaries. Floor elevations of these passes exceed 7500 feet (2286 meters) with the highest point on this divide segment being 8251 feet (2515 meters). The multiple closely spaced passes notched into this drainage divide suggest diverging and converging streams of south-oriented water flowing from what is now the north-oriented Missouri River valley to the south-oriented Boulder River once crossed the region.

After turning in a southeast direction the Missouri River-Boulder River drainage divide decreases in elevation and is again crossed by passes linking other north-oriented Prickly Pear Creek tributaries (flowing to the Missouri River) with south-oriented Boulder River tributaries before turning again in a west-toeast direction where it is crossed by the deep pass number 20 (seen in Figure 9), which is today used as a major transportation route. The pass links the north-northeast oriented Beavertown Creek valley with the south-oriented $\mathrm{Mu}$ skrat Creek valley (also known as the Boulder Valley) and has a floor elevation of 5609 feet (1710 meters). Beavertown Creek joins north-northeast oriented Prickly Pear Creek, which then flows to a northwest-oriented Missouri River segment (see Figure 1). Muskrat Creek flows through the wide Boulder Valley to join a southeast-oriented Boulder River segment, which then turns in a south direction to join a southeast- and northeast-oriented Jefferson River segment, which proceeds to join the north-oriented Madison and Gallatin Rivers at Three Forks to form the north- and northwest-oriented Missouri River. Pass number 20 must have been eroded by large volumes of south-oriented water that diverged from south-oriented flow on the modern day north-oriented Missouri River alignment to reach the south-oriented Boulder River valley.

\subsection{Boulder River-Jefferson River Drainage Divide}

Figure 10 provides a topographic map of the Boulder River-Jefferson River drainage divide area (pass 1a seen in Figure 3 also is notched into the Boulder River-Jefferson River drainage divide). Two deep passes are notched into this drainage divide and are identified by the numbers 21 and 22. Pass number 21 is located south of the Boulder Valley seen in Figure 9 and links a north-oriented Boulder River tributary with the south-oriented Whitetail Deer Creek valley, 


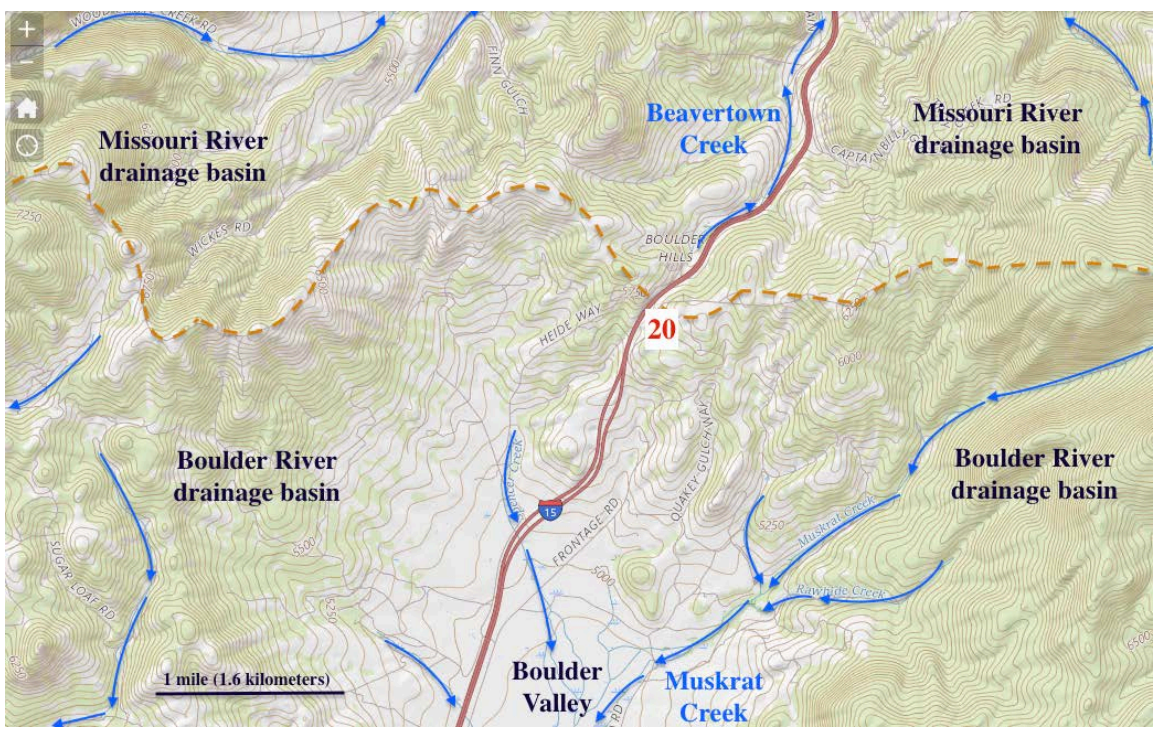

Figure 9. Modified topographic map from USGS National Map website showing the deep pass at red number 20 linking the Beaver town Creek and Muskrat Creek valleys. The dashed brown line follows the Missouri River-Boulder River drainage divide. The contour interval is 50 feet (15 meters).

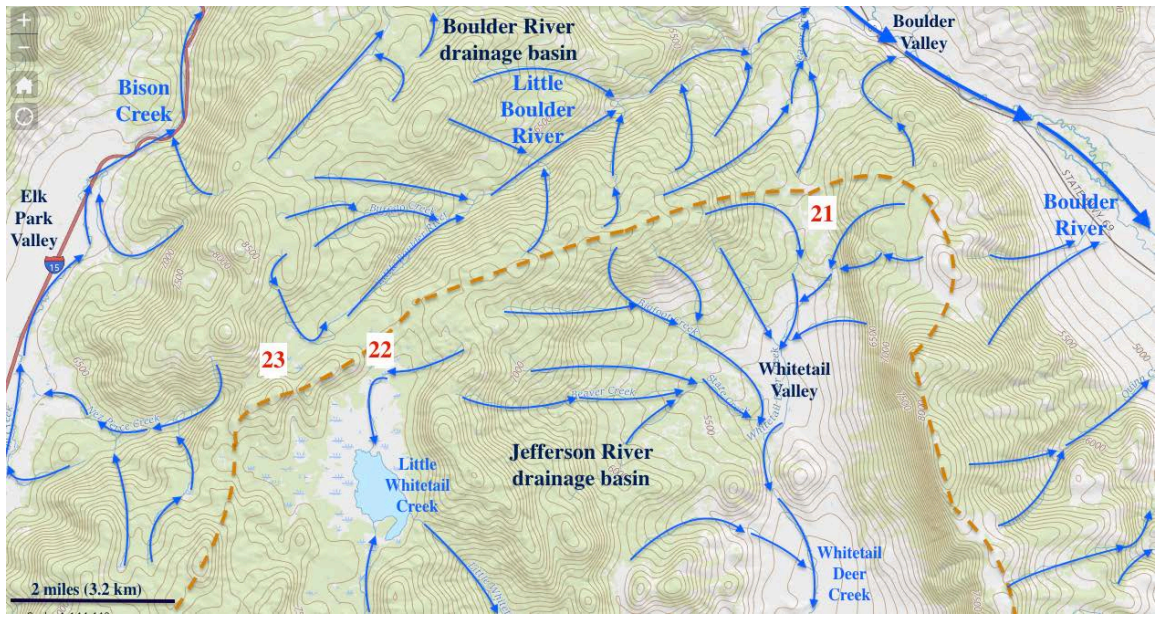

Figure 10. Modified topographic map from the USGS National Map website illustrating the Boulder River-Jefferson River drainage divide area. The dashed brown line follows the drainage divide and the contour interval is 100 feet (30.5 meters).

which drains to the Jefferson River (south of Figure 10). The floor elevation of pass 21 is 5723 feet (1744 meters), which is only slightly higher than the 5609-foot (1710-meter) elevation of pass number 20 in Figure 9. Apparently water flowed in a south direction from the present day north-oriented Missouri River valley across pass number 20 in Figure 9 and across what is now the southeast oriented Boulder River valley to reach pass number 21 in Figure 10 and then to enter the Whitetail Deer Creek valley (today the intervening Boulder Valley floor elevation is approximately 4900 feet or 1494 meters). Headward erosion of the intervening southeast-oriented Boulder River valley (perhaps aided by other geologic factors) captured south-oriented flow to the Whitetail 
Deer Creek valley and reversed the north end of the beheaded south-oriented flow channel to create the north-oriented Boulder River tributary seen today.

Pass number 22 is much higher than pass number 21 and has a floor elevation of slightly less than 7400 feet (2256 meters) and links the northeast-oriented Little Boulder River valley with the south-oriented headwaters of Little Whitetail Creek, which south of Figure 10 joins Whitetail Deer Creek with water flowing to the Jefferson River. The pass floor consists of several channels separated by low hills in a zone approximately 2 miles ( 3.2 kilometers) wide that is approximately 400 feet (122 meters) lower in elevation than the Boulder River-Jefferson River drainage divide elevations on either side. The floor elevation of pass number 22 is almost identical to the floor elevation of pass number 23, which does not cross the Boulder River-Jefferson River drainage divide, but instead links the northeast-oriented Little Boulder River valley with the southwest-oriented headwaters of a tributary to north-northeast oriented Bison Creek, which as previously discussed flows to the Boulder River. The similarity of the two pass floor elevations strongly suggests southwest-oriented water flowing in the present day northeast-oriented Little Boulder River valley diverged with some water turning to flow in a south direction to the Little Whitetail Creek valley and the remaining water flowing in a southwest direction to enter the Elk Park Valley and then to help erode Elk Park Pass and to reach and probably cross what is today the west-oriented Silver Bow Creek headwaters valley.

\section{Discussion}

Detailed topographic map evidence permits the above-described Boulder River drainage basin area erosional landform evolution process to be deciphered, however important unanswered questions remain. For example, where did the large volumes of south-oriented water required to erode deep valleys across the Boulder Batholith originate? This question becomes even more significant when evidence from other western Montana regions is considered. Recently Clausen [21] described evidence that similar south-oriented diverging and converging stream or river channel complexes had crossed what are today the southwest Montana Anaconda, Beaverhead, Centennial, and Pioneer Mountains prior to modern day Big Hole and Beaverhead River drainage system evolution (today those rivers drain in a north direction to the northeast- and east-oriented Jefferson River, which then drains to the north-oriented Missouri River). Volumes of south-oriented water moving across the entire region must have been immense much greater than a wet climatic cycle would likely generate.

A related question arises when looking at the number of capture events required as the Boulder River drainage system evolved. Bishop [23] states, "The key process in stream capture, namely, drainage head retreat, is difficult to envisage as a normal part of drainage net evolution... Stream capture may therefore be a relatively rare event in drainage net evolution... [and] should not be routinely invoked in interpretations of long-term drainage evolution.” Regions with 
wet climates exist today, yet stream capture in those regions does not appear to occur significantly more frequently than in drier regions. Factors other than just a wet climatic cycle must have been involved as large volumes of south-oriented water eroded the modern day Boulder River drainage basin. Tectonic activity was almost certainly occurring as the large quantities of south-oriented water flowed across the region, which raises still an additional question. Why would immense quantities of south-oriented water flow across western Montana during a period when mountain ranges were uplifted while adjacent basin areas subsided? Sears et al. [18] attribute this period of tectonic activity to Yellowstone hotspot evolution, but such an explanation does not account for the volumes of water required to erode deep valleys and to transport and deposit large volumes of sediments. A different factor must be involved.

One possible source of large south-oriented volumes of water moving across western Montana that might trigger tectonic activity would be a large North American continental ice sheet. Large North American continental ice sheets are known to have existed and would have contained enough frozen water to fill a medium-sized ocean. In addition such ice sheets might have created and occupied a deep "hole" in the North American continent by depressing the continental crust beneath them, deeply eroding the underlying bedrock underneath them, and by warping the continental crust elsewhere. While the concept of deep erosion by continental ice sheets has been rejected by much of the geologic research community the concept has been proposed (see references by White [24] [25]) and Clausen [26] and [27] has recently described western South Dakota and southeastern Montana evidence for headward erosion of deep north- and northeast-oriented valleys (perhaps eroding headward from space in an ice sheet created and occupied deep "hole" that was being opened up as a large continental ice sheet melted). The north-oriented South Dakota and southeastern Montana valleys eroded headward across what may have been large and southeast-oriented ice marginal melt water floods.

Today the north-oriented Montana Missouri River valley (east of the Boulder River drainage basin) and the north- and northwest-oriented Clark Fork valley (west of the Boulder River drainage basin) both drain toward recognized continental ice sheet margin areas. It is not difficult to imagine immense floods of south-oriented melt water from a North American ice sheet (occupying an ice sheet created deep "hole") moving in those valleys and reversing their flow direction as melting opened up space in that "hole". The Boulder River drainage divide evidence described in this paper definitely supports such an interpretation. However the problem remains, large North American continental ice sheets as commonly described did not create and occupy deep "holes" and existed during Pleistocene time and the large volumes of water responsible for eroding the Boulder River probably flowed across the region prior to that time.

\section{Conclusion}

Evidence presented and illustrated in this paper makes it possible to describe in 
detail how the Boulder River drainage basin evolved from a large complex of diverging and converging south-oriented stream or river channels that previously crossed the region to the drainage system that exists today. This evolutionary process occurred as numerous stream capture events repeatedly funneled southoriented water into fewer and fewer and deeper and deeper channels while at the same time reversing flow on north ends of the beheaded channels so as to create new drainage divides. While hundreds and possibly thousands of capture events were taking place tectonic activity probably was also raising the Boulder Batholith area while the adjacent basin areas (e.g. Deer Lodge Graben) subsided under the weight of accumulating sedimentary deposits. Further work is needed to determine the south-oriented water source and to better relate the Boulder River drainage system evolution with sedimentary deposits found in the nearby valleys and basins. However, whenever large volumes of water crossed the region and whatever the source the water that eroded the Boulder River drainage basin flowed in south direction.

\section{References}

[1] Calhoun, F.H.H. (1906) The Montana Lobe of the Keewatin Ice Sheet. United States Geological Survey Professional Paper 50.

[2] Alden, W.C. (1932) Physiography and Glacial Geology of Eastern Montana and Adjacent Areas. U.S. Geol. Survey Prof. Paper 174.

[3] Atwood, W.W. (1916) The Physiographic Conditions at Butte, Montana, and Bingham Canyon, Utah, When the Copper in These Districts Was Enriched. Economic Geology, 11, 697-749. https://doi.org/10.2113/gsecongeo.11.8.697

[4] Sears, J.W. (2013) Late Oligocene-Early Miocene Grand Canyon: A Canadian Connection? GSA Today, 23, 4-10. https://doi.org/10.1130/GSATG178A.1

[5] Clausen, E. (2014) Comment: Late Oligocene-Early Miocene Grand Canyon: A Canadian Connection? Online: GSA Today, Comments and Replies. https://www.geosociety.org/gsatoday/comment-reply/pdf/i1052-5173-24-4-e32.pdf

[6] Sears, J.W. (2014) Reply to Comment: "Late Oligocene-Early Miocene Grand Canyon: A Canadian connection?” Online: GSA Today, Comments and Replies. https://www.geosociety.org/gsatoday/comment-reply/pdf/i1052-5173-24-4-e33.pdf

[7] Church, S.E., Nimick, D.A., Finger, S.E. and O’Neill, J.M. (2007) The Boulder River Watershed Study, Jefferson County, Montana. In: Nimick, D.A., Church, S.E. and Finger, S.E., Eds., Chapter B, Integrated Investigations of Environmental Effects of Historical Mining in the Basin and Boulder Mining Districts, Boulder River Watershed, Jefferson County, Montana, United States Geological Survey Professional Paper 1652-B, 697-740.

[8] Woodward, L.A. (1986) Tectonic Origin of Fractures for Fissure Vein Emplacement in the Boulder Batholith and Adjacent Rocks, Montana. Economic Geology, 81, 1387-1395. https://doi.org/10.2113/gsecongeo.81.6.1387

[9] Ruppel, E.T. (1963) Geology of the Basin Quadrangle Jefferson, Lewis and Clark, and Powell Counties, Montana. United States Geological Survey Bulletin, 1151.

[10] Smedes, H.W. (1962) Lowland Creek Voleanics, an Oligocene Formation near Butte, Montana. The Journal of Geology, 70, 255-266. https://doi.org/10.1086/626818

[11] Smedes, H.W. and Thomas, H.H. (1965) Reassignment of the Lowland Creek Vol- 
canics to Eocene Age. The Journal of Geology, 73, 508-510. https://doi.org/10.1086/627082

[12] Dudas, F.O., Ispolatov, V.O., Harlan, S.S. and Snee, L.W. (2010) 40Ar/39Ar Geochronology and Geochemical Reconnaissance of the Eocene Lowland Creek Volcanic Field, West-Central Montana. The Journal of Geology, 118, 295-304. https://doi.org/10.1086/651523

[13] Becraft, G.E., Pinckney, D.M. and Rosenblum, S. (1963) Geology and Mineral Deposits of the Jefferson City Quadrangle, Jefferson and Lewis and Clark Counties, Montana. United States Geological Survey Professional Paper 428.

[14] Ruppel, E.T. (1962) A Pleistocene Ice Sheet in the Northern Boulder Mountains Jefferson, Powell, and Lewis and Clark Counties, Montana. United States Geological Survey Bulletin 1141-G.

[15] Alt, D.D. and Hyndman, D.W. (1986) Roadside Geology of Montana. Mountain Press Publishing Company, Missoula.

[16] Thompson, G.R., Fields, R.W. and Alt, D. (1982) Land-Based Evidence for Tertiary Climatic Variations: Northern Rockies. Geology, 10, 413-417. https://doi.org/10.1130/0091-7613(1982)10<413:LEFTCV>2.0.CO;2

[17] Retallack, G.J. (2007) Cenozoic Paleoclimate on Land in North America. The Journal of Geology, 115, 271-294. https://doi.org/10.1086/512753

[18] Sears, J.W., Hendrix, M.S., Thomas, R.C. and Fritz, W.J. (2009) Stratigraphic Record of the Yellowstone Hotspot Track, Neogene Sixmile Creek Formation Grabens, Southwest Montana. Journal of Volcanology and Geothermal Research, 188, 250-259. https://doi.org/10.1016/j.jvolgeores.2009.08.017

[19] United States Geological Survey National Map. https://viewer.nationalmap.gov/advanced-viewer/

[20] Baker, V.R. (1981) Large-Scale Erosional and Depositional Features of the Channel Scabland. In: Baker, V.R., Ed., Catastrophic Flooding; The Origin of the Channeled Scabland, Dowden, Hutchinson and Ross Inc., Stroudsburg, 276-310.

[21] Clausen, E. (2017) Origin of Mountain Passes across Continental Divide Segments Surrounding the Southwest Montana Big Hole and Beaverhead River Drainage Basins, USA. Open Journal of Geology, 7, 1362-1385.

https://doi.org/10.4236/ojg.2017.79091

[22] Sears, J.W. and Ryan, P. (2003) Cenozoic Evolution of the Montana Cordillera: Evidence from Paleovalleys. In: Raynolds, R. and Flores, J., Eds., Cenozoic Paleogeography of Western US: Rocky Mountain Section, Society of Exploration Paleontologists and Mineralogists, Denver, 289-301.

[23] Bishop, P. (1995) Drainage Rearrangement by River Capture, Beheading and Diversion. Progress in Physical Geography, 19, 449-473.

https://doi.org/10.1177/030913339501900402

[24] White, W.A. (1972) Deep Erosion by Continental Ice Sheets. Geological Society of America Bulletin, 81, 1037-1056. https://doi.org/10.1130/0016-7606(1972)83[1037:DEBCIS]2.0.CO;2

[25] White, W.A. (1988) More on Deep Glacial Erosion by Continental Ice Sheets and Their Tongues of Distributary Ice. Quaternary Research, 30, 137-150. https://doi.org/10.1016/0033-5894(88)90019-1

[26] Clausen, E. (2017) Solving a Perplexing Scenic and Sage Creek Basin Drainage History Problem, Pennington County, South Dakota, USA. Journal of Geography and Geology, 9, 1-10. 
[27] Clausen, E. (2017) Origin of Little Missouri River-South Fork Grand River and nearby Drainage Divides in Harding County, South Dakota and Adjacent Eastern Montana, USA. Open Journal of Geology, 7, 1063-1077.

https://doi.org/10.4236/ojg.2017.78071 